\title{
Does Telemedicine Reduce health disparities? Longitudinal Evidence during the COVID-19 Pandemic in the US
}

\author{
Ali Roghani ${ }^{1}$, Samin Panahi ${ }^{1}$ \\ 1- Division of Epidemiology - University of Utah \\ Corresponding author: Ali Roghani \\ Email: ali_roghani@hotmail.com
}

\begin{abstract}
Objective:
The COVID-19 pandemic could be a significant health issue for the elderly population and those with pre-excising chronic condition. In response to the pandemic health care services have increased the use of telehealth medicine. The propose of this study is to examine factors associated with access to telemedicine before and after COVID-19 based on sociodemographic factors and type of chronic disease.
\end{abstract}

\section{Method:}

We have used data from the Research and Development Survey (RANDS) at two different time points Data collection for the first wave occurred between June 9, 2020 and July 6, $2020(\mathrm{n}=6786)$, second wave was between August 3, 2020 and August 20, $2020(\mathrm{n}=5972)$. Three questions have been asked from the participant: 1) did the provider offer telemedicine before the pandemic? 2) does the provider offer telemedicine during the pandemic? And 3) have the participants schedule telemedicine appointments?

\section{Result:}

In both waves, $62 \%$ of the participants reported providers did not have telemedicine services prior to the COVID-19 pandemic. However, we found a $22 \%$ increase in offering telemedicine in six first month of the COVID-19 pandemic. The finding shows almost no change in providing telemedicine between June and August. The data indicates just a $0.5 \%$ and $0.1 \%$ increase in accessing telemedicine, and scheduling in August than June, respectively. Patients older than 65 had higher access to telemedicine and had higher scheduling frequencies than other age groups, while they had the lowest access prior to the COVID-19. Blacks had the highest access to telemedicine services than other races (40\%). Additionally, females, higher education, and living in metropolitan areas were associated with higher access and scheduling during the pandemic. There was a variation of access and scheduling in different chronic diseases, however, providers offered more remote services for those who diagnosed by diabetes.

\section{Conclusion:}

The aim of telemedicine is to reduce disparities in healthcare access. The findings of this study show telemedicine has reduced racial disparities and provided greater accessibility for older groups. However, spatial and educational disparities are still noticeable. Research is necessary to examine how healthcare must address the socioeconomic heterogeneity in telemedicine by avoiding further disparities.

\section{Key terms:}

COVID-19, Telemedicine, health disparities, chronic condition, access to care 
medRxiv preprint doi: https://doi.org/10.1101/2021.03.01.21252330; this version posted March 2, 2021. The copyright holder for this preprint (which was not certified by peer review) is the author/funder, who has granted medRxiv a license to display the preprint in perpetuity.

\section{Introduction}

Novel Coronavirus Disease (COVID-19) is an infectious disease that has emerged worldwide by creating a pandemic in early 2020 (1). The COVID-19 Pandemic could be a significant health issue for the elderly population and individuals with pre-excising chronic conditions (e.g., hypertension, heart problems, and diabetes), who are more susceptible to developing the disease and have a higher risk of death $(1,2)$. In response to the pandemic, social distasting has played an important factor in slowing down the virus's transmission. Telehealth is the delivery of health care services by health care professionals and currently is an essential tool in providing health care while providing patient and providers safe from COVID-19 $(5,6)$. Therefore, health care services have increased the use of telehealth medicine $(3,4)$. The purpose of this study is to examine factors associated with access to telemedicine and scheduling before and after COVID-19 based on sociodemographic factors and the type of chronic disease. This study assesses access and scheduling telemedicine by age-group (e.g., 18-44,45-64, and 65+), race (e.g., White, Black, Hispanic, and other races), sex(males vs. females), educational status (high school or less, some college, bachelor's degree or above), and urbanization ( metropolitan vs. non-metropolitan). Research and Development Survey (RANDS) is longitudinal data that asks the participants in two points of time (June and August), which allows us to compare accessing and scheduling before and after COVID-19 and the progress of using telemedicine. This study, additionally, compares patients using telemedicine-based on chronic disease types to see which types of chronic diseases are more likely to be adopted for telemedicine faster in crisis moments.

Recent research has reported that during the COVID-19 pandemic, there are significantly lower levels of telehealth medicine usage among Black patients and the older population than their White counterparts (7). Instructional factors such as discrimination and segregation significantly affect the ability to access healthcare in an unfortunate event such as the COVID-19 pandemic. In addition, increase social vulnerability, including racial disparities, is associated with health inequalities (8). For example, one study has shown that COVID-19 exposure and death were higher among African American populations 
medRxiv preprint doi: https://doi.org/10.1101/2021.03.01.21252330; this version posted March 2, 2021. The copyright holder for this preprint (which was not certified by peer review) is the author/funder, who has granted medRxiv a license to display the preprint in perpetuity.

All rights reserved. No reuse allowed without permission.

because they are disproportionately affected by multiple chronic diseases (9). A recent study in 2020 indicates that half of the sample were willing to use videoconferencing visits, and individuals who were older than 65 years $(\mathrm{OR}, 0.51)$ or had less education $(\mathrm{OR}, 0.37)$ were less likely to express willingness to have a telehealth appointment (10). Previous research shows that it is highly likely to have health disparities in non-metropolitan areas, and rural hospitals were less likely to use telehealth systems, such as checking patients' health information online (11). Telehealth services are mostly for non-lifethreatening health care; thus, there is a variation between the types of diseases in telemedicine. Dena (2020) shows individuals are more likely to have telehealth appointments for cardiovascular or metabolic disorders, mental health problems than autoimmune and respiratory diseases. Previous research examines the relationships between telemedicine and health disparities, including a few demographic measures, while this research includes these factors comprehensively in a longitudinal method.

In the following sections, the changes and progress of accessing and scheduling telemedicine in the first six months of the COVID-19 outbreak will be presented.

\section{Data and Results}

This research uses data from the Research and Development Survey (RANDS) to administer survey question evaluation and statistical research. RANDS is a continuous range of studies for methodological research at the National Center for Health Statistics (NCHS). This research includes experimental evaluations of telemedicine access and uses for two rounds of RANDS during COVID-19. Data collection for the first wave occurred between June 9, 2020, and July 6, 2020, and data collection for the second wave was between August 3, 2020, and August 20, 2020. In the following sections, the percentage of telemedicine access before and after the pandemic and scheduling are presented. 
Table 1 Summary of the Measures

\begin{tabular}{|c|c|c|}
\hline & June & August \\
\hline \multicolumn{3}{|l|}{ Age group } \\
\hline $18-44$ years & 38.41 & 37.03 \\
\hline 45-64 years & 35.07 & 34.81 \\
\hline 65 years and over & 26.51 & 28.14 \\
\hline \multicolumn{3}{|l|}{ Race } \\
\hline White non-Hispanic & 66.4 & 68.2 \\
\hline Black non-Hispanic & 11.95 & 11.53 \\
\hline Other non-Hispanic & 7.79 & 7.71 \\
\hline Hispanic & 13.85 & 12.54 \\
\hline \multicolumn{3}{|l|}{ Sex } \\
\hline Male & 43.66 & 43.33 \\
\hline Female & 56.34 & 56.67 \\
\hline \multicolumn{3}{|l|}{ Education } \\
\hline High school graduate or less & 19.06 & 18.45 \\
\hline Some college & 37.6 & 37.24 \\
\hline Bachelor's degree or above & 43.34 & 44.3 \\
\hline \multicolumn{3}{|l|}{ Urbanization } \\
\hline Metropolitan & 89.15 & 88.9 \\
\hline Non-Metropolitan & 10.85 & 11.1 \\
\hline \multicolumn{3}{|l|}{ Provider offers telemedicine } \\
\hline Yes & 36.6 & 37.1 \\
\hline No & 46.9 & 48 \\
\hline Do not know & 5.2 & 5.4 \\
\hline
\end{tabular}




\begin{tabular}{|lcr|}
\hline \multicolumn{2}{|l}{ No usual place of care } & \multicolumn{2}{l}{9.5} \\
Provider offered telemedicine prior to pandemic & 14.1 & 14.1 \\
Yes & 61.7 & 62.6 \\
No & 12.9 & 13.8 \\
Do not know & 11.3 & 9.5 \\
No usual place of care & & \\
Scheduled one or more telemedicine appointments \\
Yes & 24.2 & 24.3 \\
No & 17.3 & 17.9 \\
No telemedicine available & 58.5 & 57.8 \\
\hline
\end{tabular}

In June 2020, the first wave was asked ( $n=6786)$, and the second wave was collected in August ( $n=5972)$. Three different questions were asked concerning telemedicine before and after COVID-19. The questions are 1) did the provider offer telemedicine before the pandemic? 2) does the provider offer telemedicine during the pandemic? And 3) have the participants schedule telemedicine appointments? The data includes age group, race, sex, education, urbanization status, and scheduling appointments by chronic diseases during the COVID-19 pandemic. In the first wave, around 37\% of the sample had access to telemedicine, and $47 \%$ reported no access. There was no considerable change in the second round; however, $48 \%$ of the sample did not access telemedicine. In both waves, $62 \%$ of the participants reported providers did not have telemedicine services prior to the COVID-19 pandemic. One out of four of the participants scheduled at least a telemedicine appointment in both rounds. There is no specific change in the distribution of demographic indicators in both waves. More than $25 \%$ of the sample were 65 years and over. Whites were the majority of the sample (66\%), and $56 \%$ of the respondents were females. Less than $20 \%$ of the sample had high school or less, and close to $90 \%$ of the respondents from metropolitan areas. 
medRxiv preprint doi: https://doi.org/10.1101/2021.03.01.21252330; this version posted March 2, 2021. The copyright holder for this preprint (which was not certified by peer review) is the author/funder, who has granted medRxiv a license to display the preprint in perpetuity.

All rights reserved. No reuse allowed without permission.

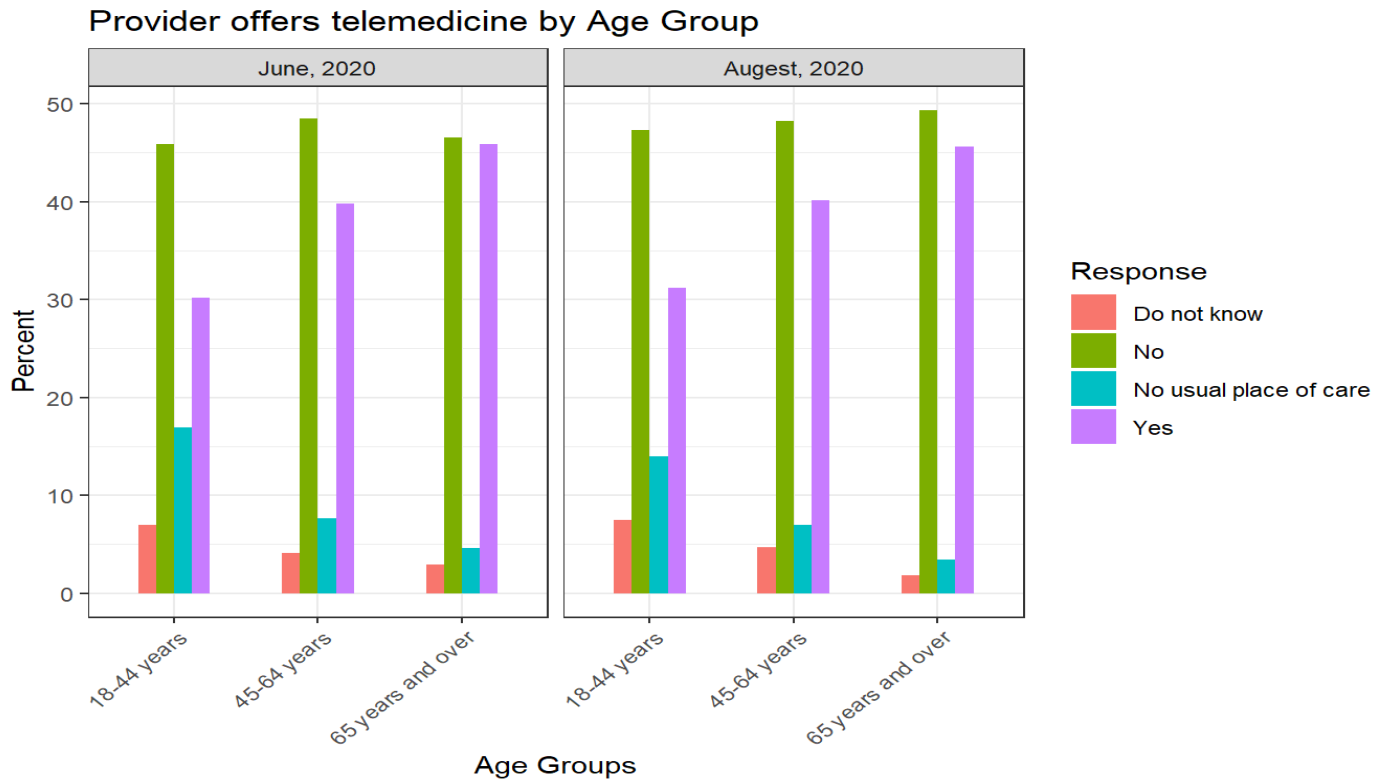

Provider Offered Telemedicine prior to Pandemic by Age Group

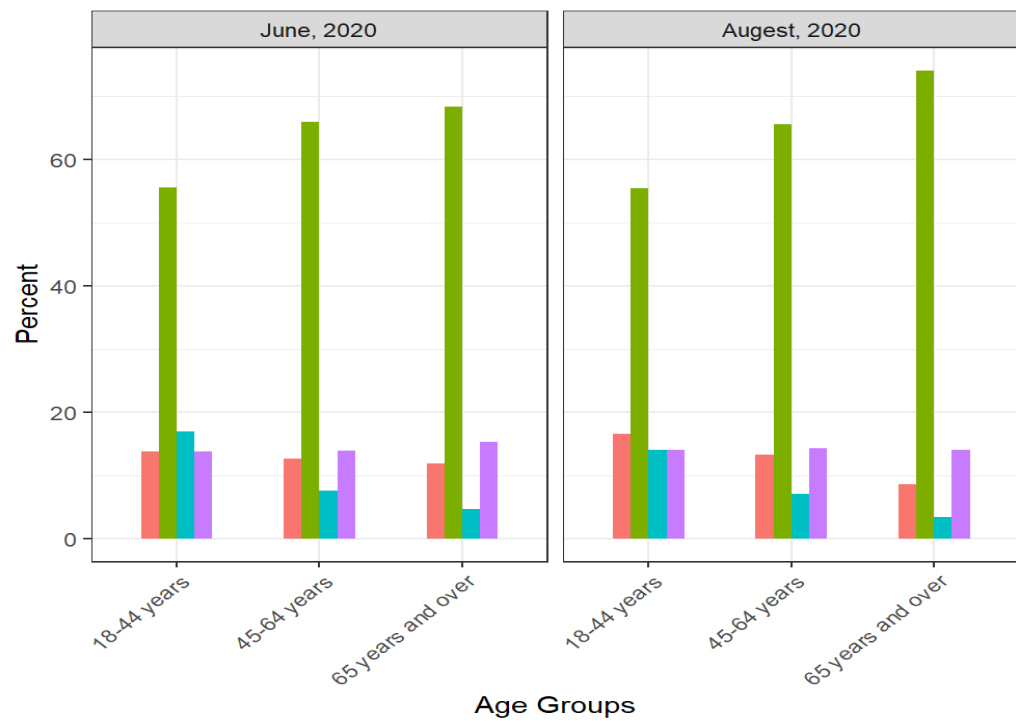

Response

Do not know

No

No usual place of care

Yes

Age Groups

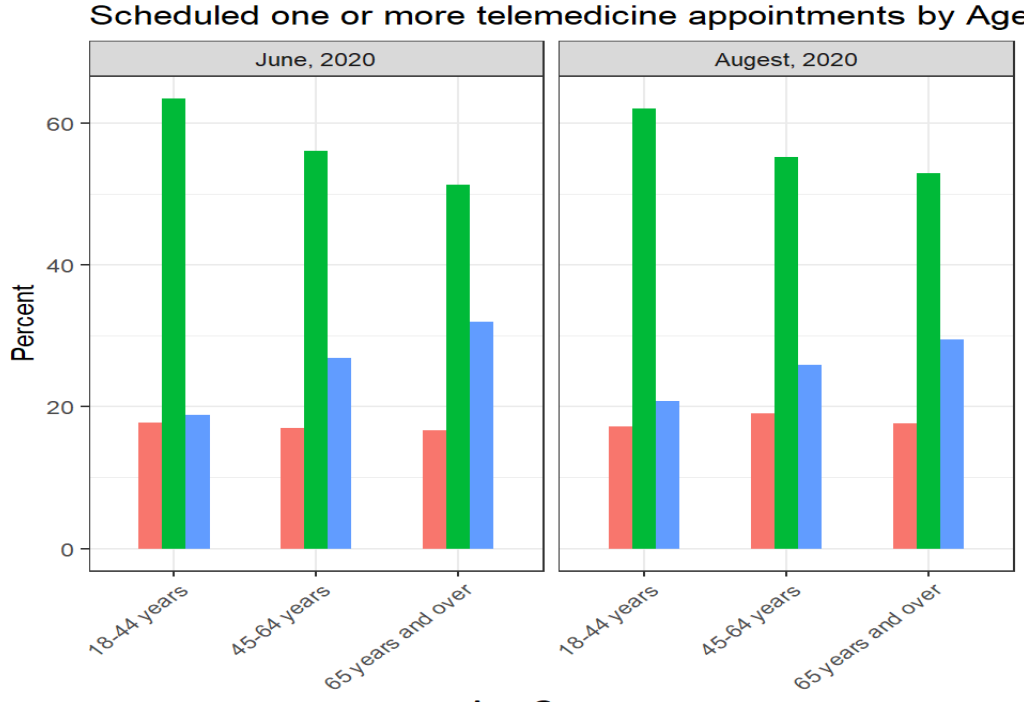

Response

No

No telemedicine available

Yes

Age Groups 
medRxiv preprint doi: https://doi.org/10.1101/2021.03.01.21252330; this version posted March 2, 2021. The copyright holder for this preprint (which was not certified by peer review) is the author/funder, who has granted medRxiv a license to display the preprint in perpetuity.

All rights reserved. No reuse allowed without permission.
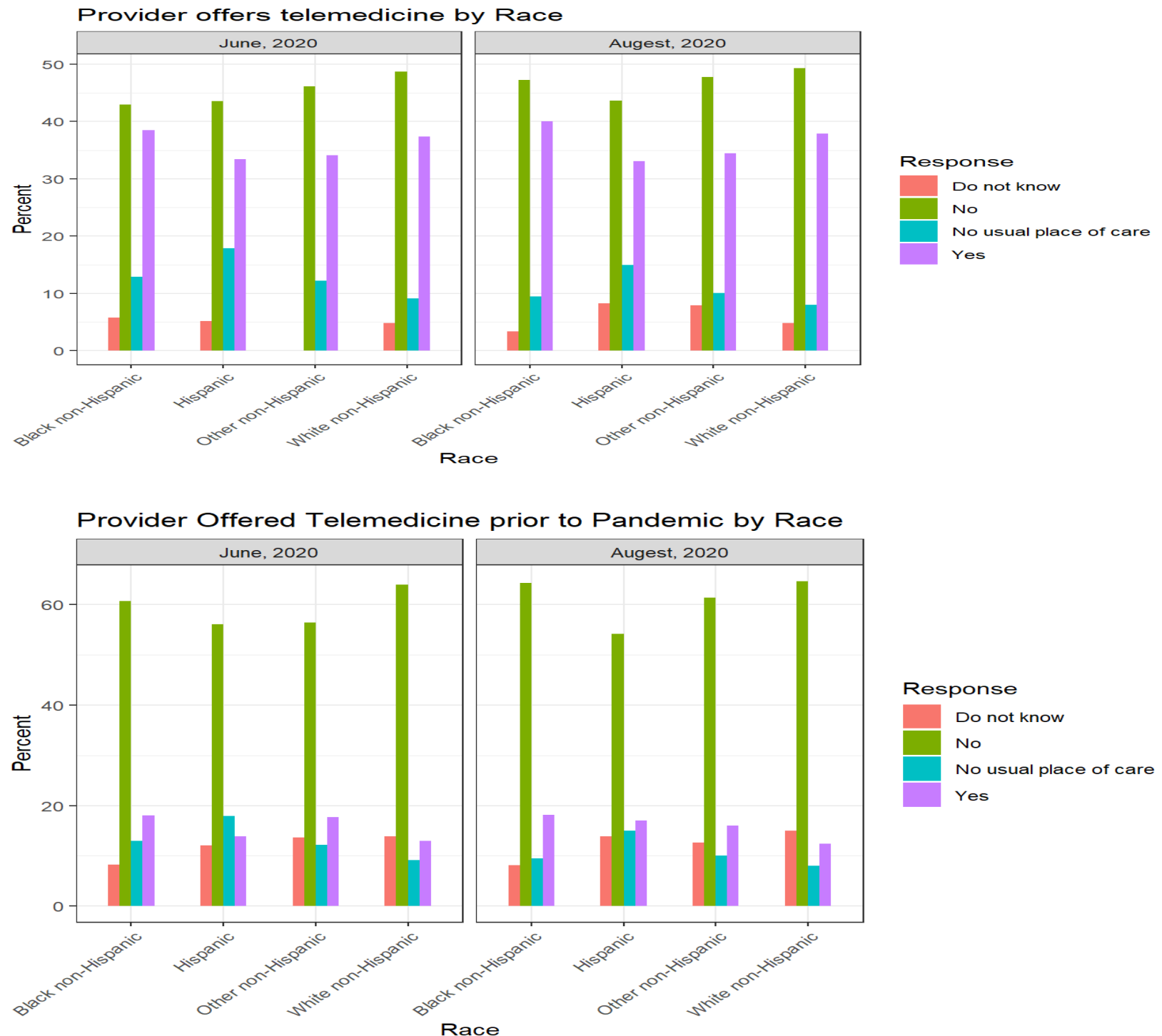

Response

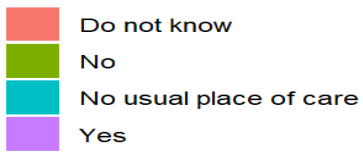

Scheduled one or more telemedicine appointments by Race

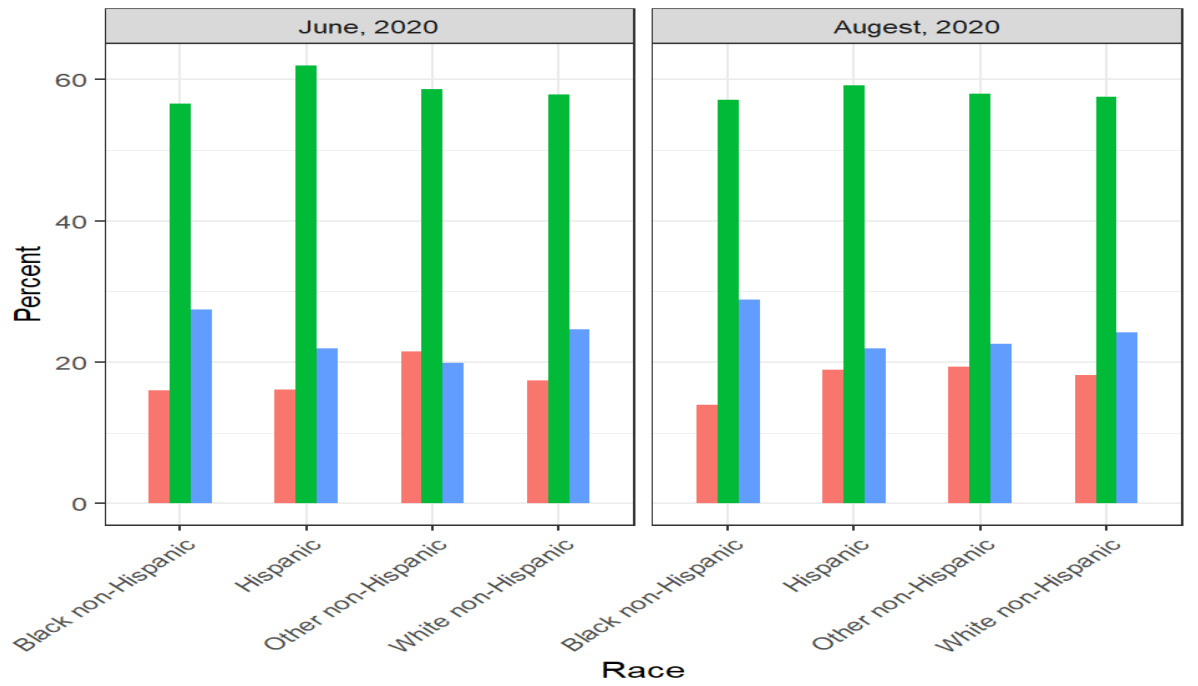

Response

No

No telemedicine available

Yes 
medRxiv preprint doi: https://doi.org/10.1101/2021.03.01.21252330; this version posted March 2, 2021. The copyright holder for this preprint (which was not certified by peer review) is the author/funder, who has granted medRxiv a license to display the preprint in perpetuity.

All rights reserved. No reuse allowed without permission.

Results show that those older than 65 had higher access to telemedicine and had higher scheduling frequencies than other age groups. People who older than 65 reported $45 \%$ of providers offered telemedicine, while those between 18-44 reported $30 \%$ of providers had telemedicine services. Prior the pandemic, however, around 75 percent of people who were older than 65 reported the provider did not offer telemedicine. Blacks had the highest access to telemedicine services than other races(40\%), and Whites had the next position(37\%). Additionally, Blacks and Whites were more likely to visit doctors through telemedicine (close to 25\%) than other races. Although there were no considerable differences between races in accessing telemedicine before the pandemic, Blacks had better outcomes than other races. Females were more likely to access and schedule during the COVID-19 pandemics than males, while females and males had the same performance before the pandemic. The results indicate $40 \%$ of those with academic education reported accessing telemedicine, which was the highest percentage among other educational levels. Also, people with lower educational levels had higher rates of accessing telemedicine in August than June. Before the pandemic, there were no significant differences in accessing telemedicine based on educational level.

Although urbanization did not change people's access to telemedicine, people who lived in nonmetropolitan had slightly lower access in August than June. In the first round, participants in nonmetropolitan areas reported $36 \%$ of providers offer telemedicine, while the access decreased $6 \%$ in August. This reduction was the same for scheduling for non-metropolitan regions in August. The findings indicate there was a variation in chronic disease types offered by providers during COVID-19. More than 55\% of people diagnosed with diabetes could use telemedicine, while providers offer services around $40 \%$ for other chronic diseases. By comparison two rounds, the results show no change in the second round in providing telehealth by health care. More than $40 \%$ of respondents who had diabetes reported at least one appointment through telemedicine, while $30 \%$ of patients with other chronic diseases had an online session. There was not a difference in offering telemedicine sessions for patients with the chronic disease before the pandemic. 
medRxiv preprint doi: https://doi.org/10.1101/2021.03.01.21252330; this version posted March 2, 2021. The copyright holder for this preprint (which was not certified by peer review) is the author/funder, who has granted medRxiv a license to display the preprint in perpetuity.

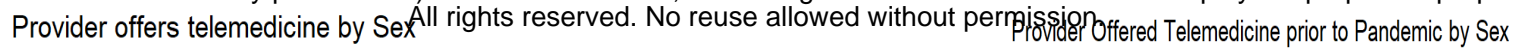

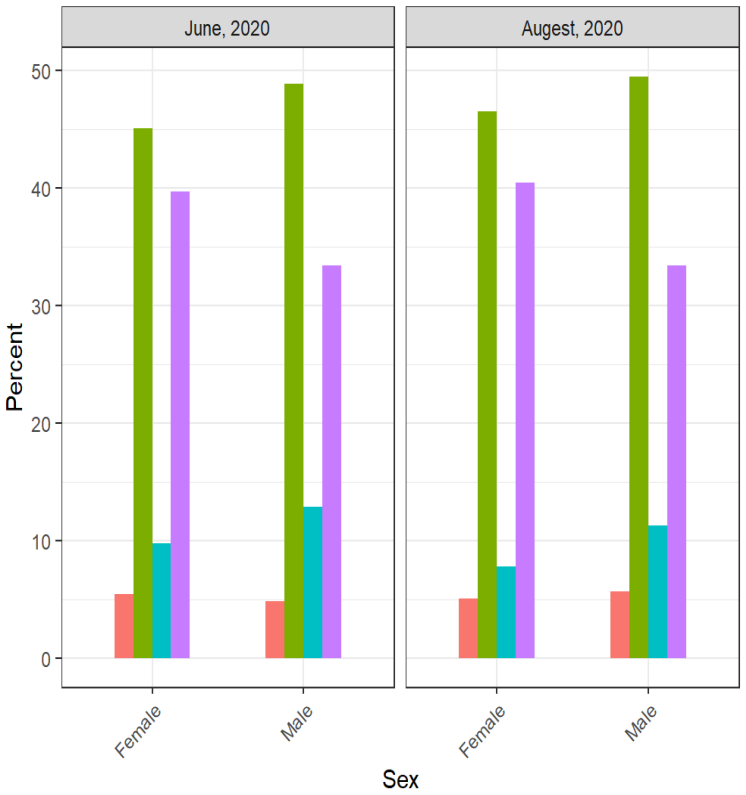

Scheduled one or more telemedicine appointments by Sex

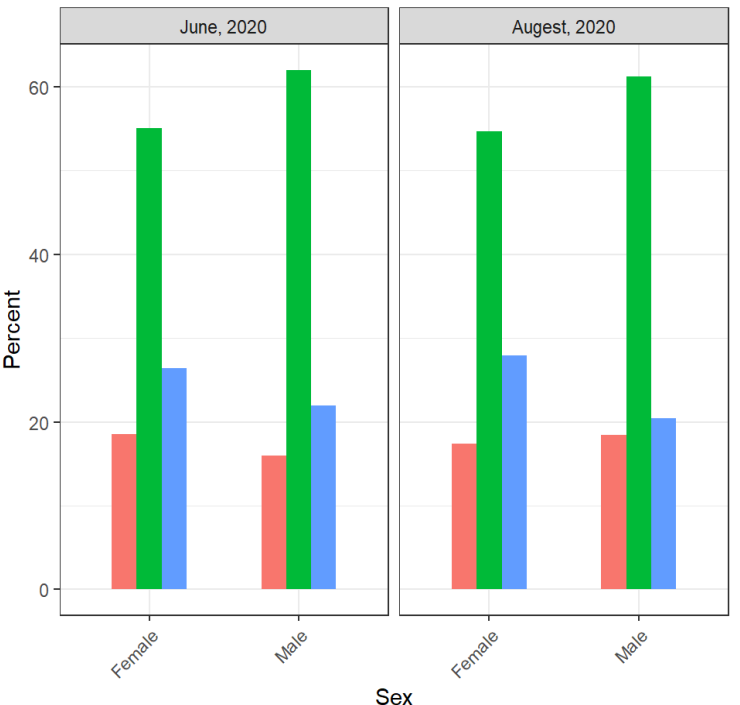

Provider Offered Telemedicine prior to Pandemic by Urbanization

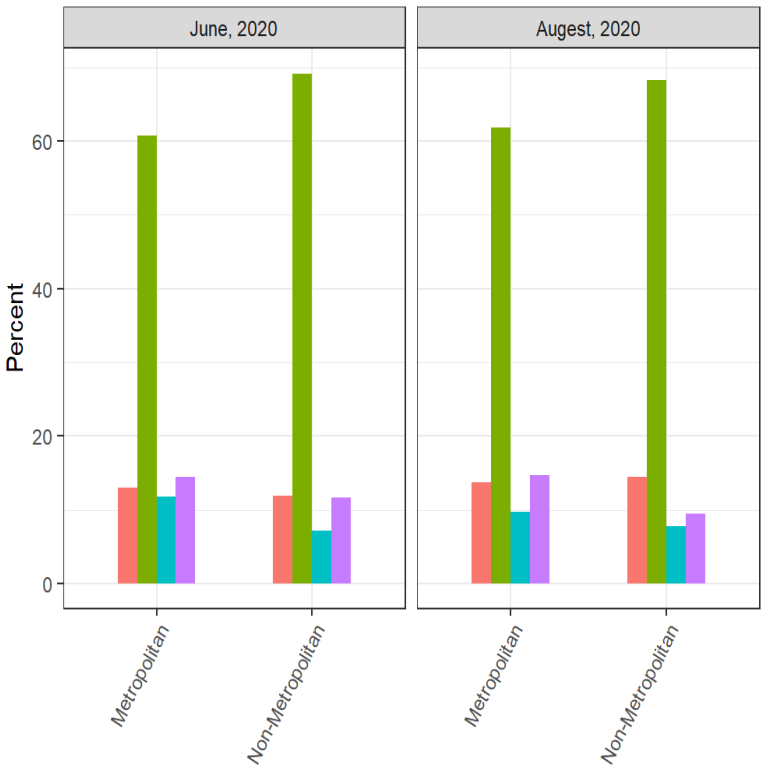

Urbanization

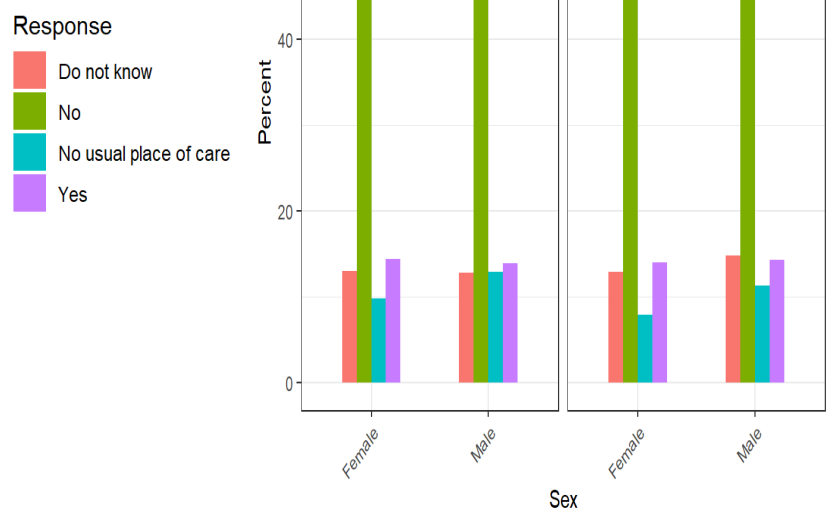

Provider offers telemedicine by Urbanization
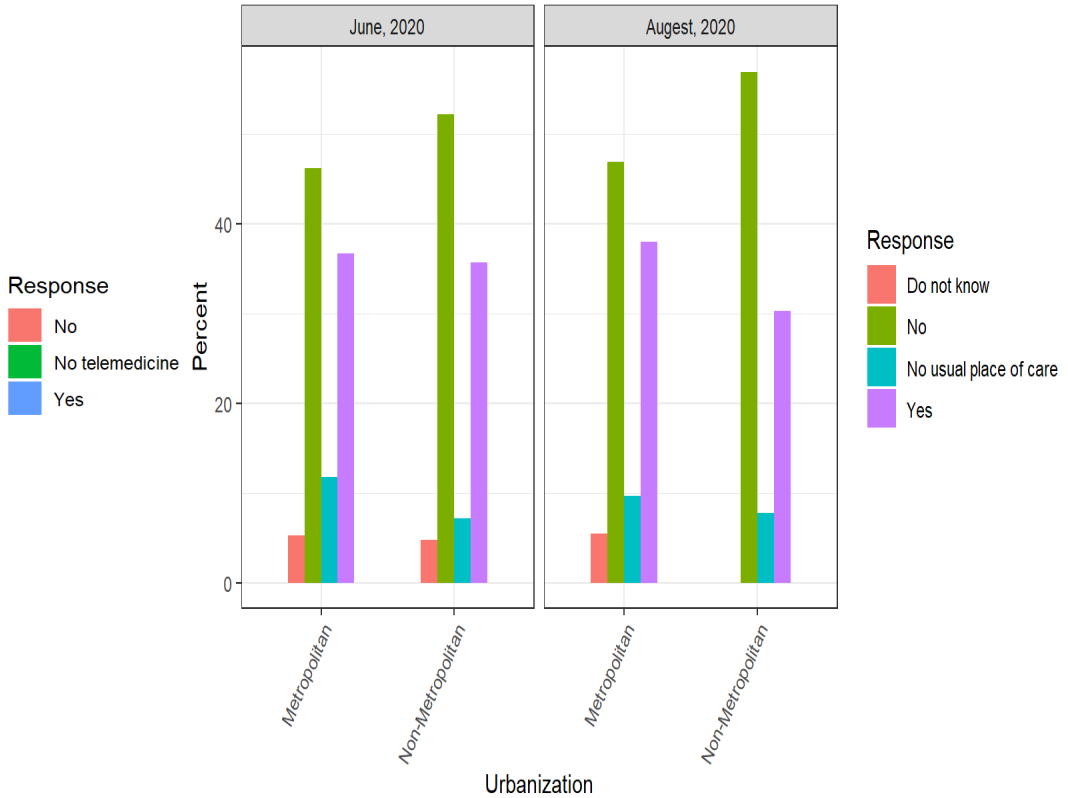

Scheduled one or more telemedicine appointments by Urbanization

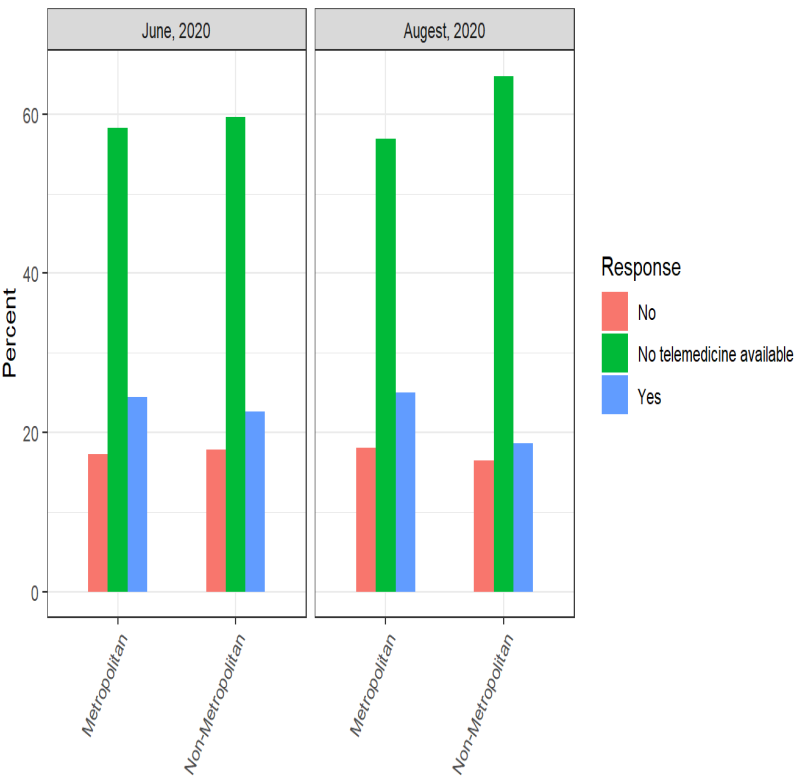

Urbanization

Response

Do not know

No

No usual place of care

Yes

sponse

No

usual place of care Yes

Response

Do not know

No

No usual place of care

Yes 
medRxiv preprint doi: https://doi.org/10.1101/2021.03.01.21252330; this version posted March 2, 2021. The copyright holder for this preprint (which was not certified by peer review) is the author/funder, who has granted medRxiv a license to display the preprint in perpetuity.

Provider offers tellemedicine by Education

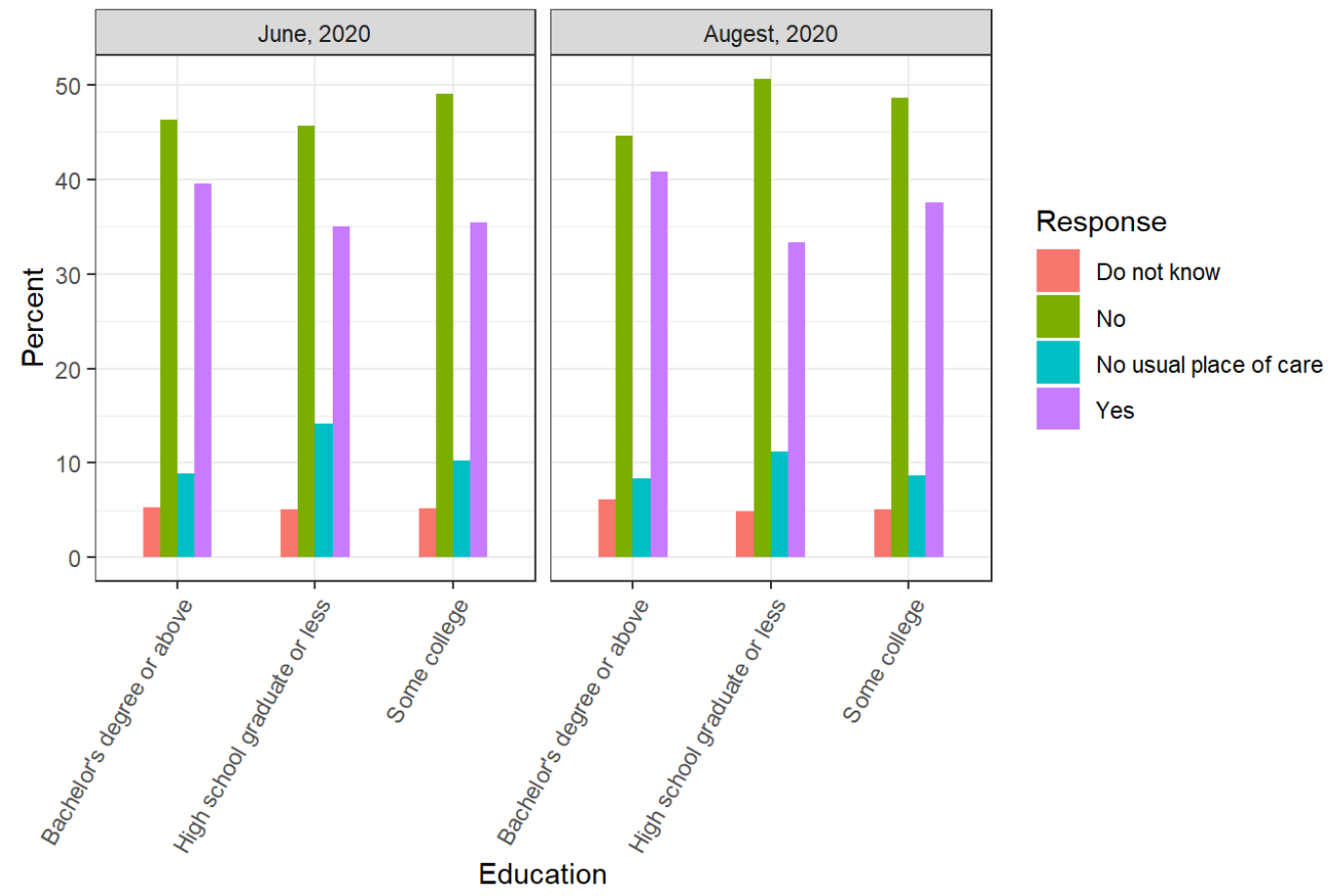

\section{Provider Offered Telemedicine prior to Pandemic by Education}
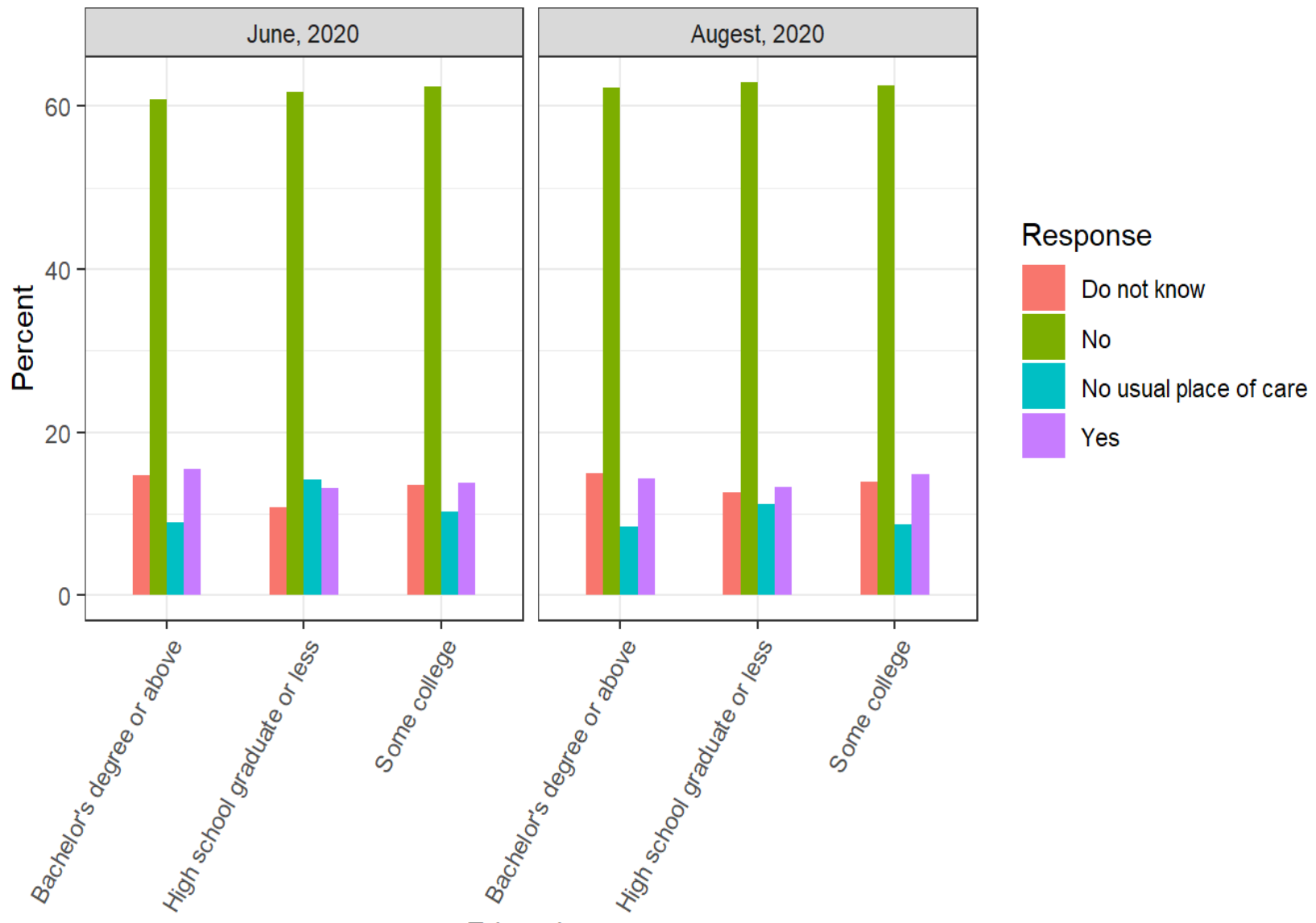

Education 
medRxiv preprint doi: https://doi.org/10.1101/2021.03.01.21252330; this version posted March 2, 2021. The copyright holder for this preprint (which was not certified py peer review) is the author/funder, who has granted medRxiv a license to display the preprint in perpetuity.
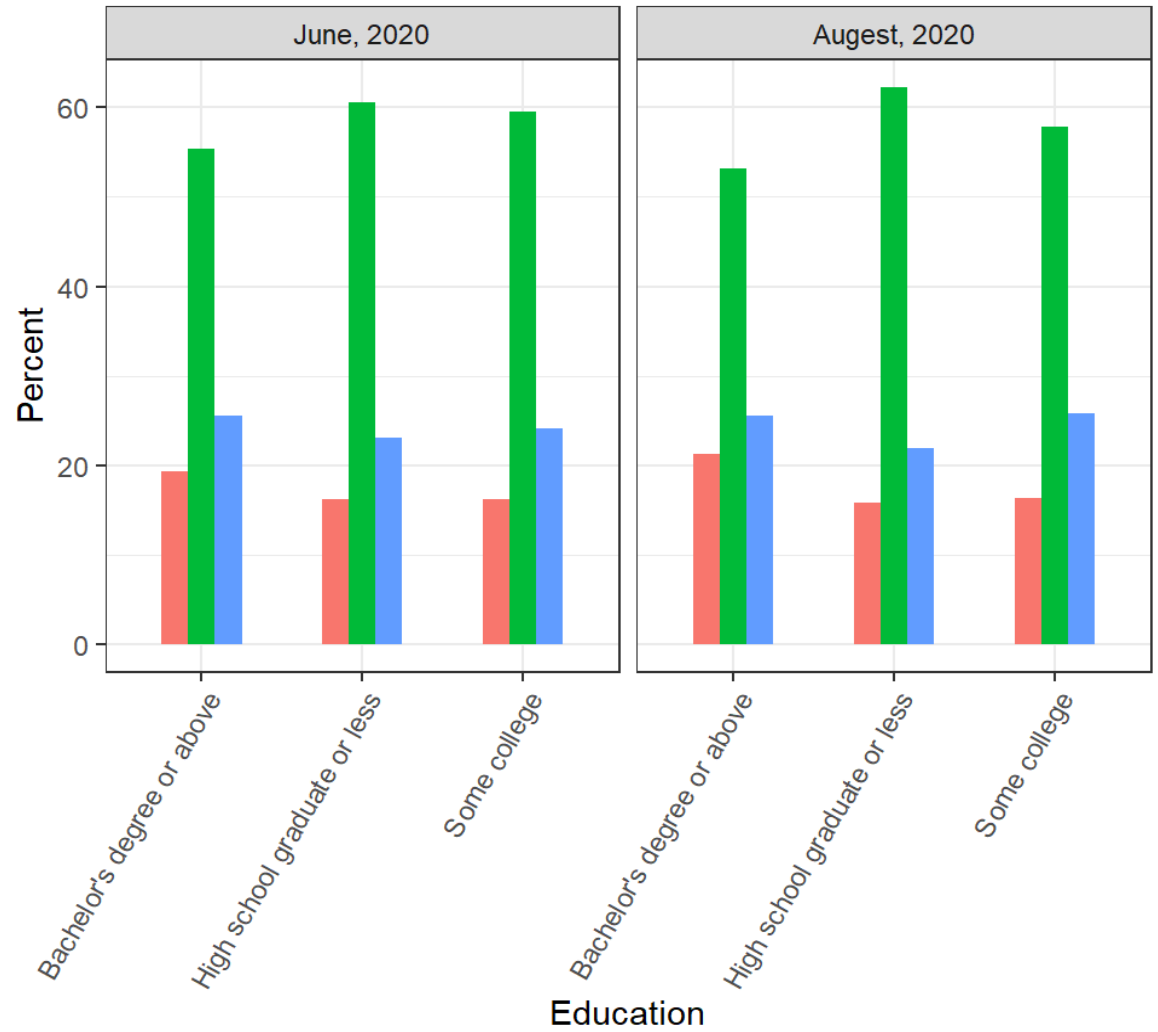

\section{Response}

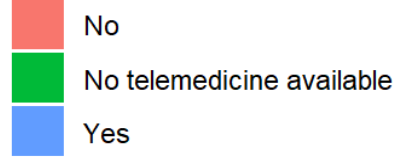

Education

\section{Provider offers telemedicine by Chronic conditions}
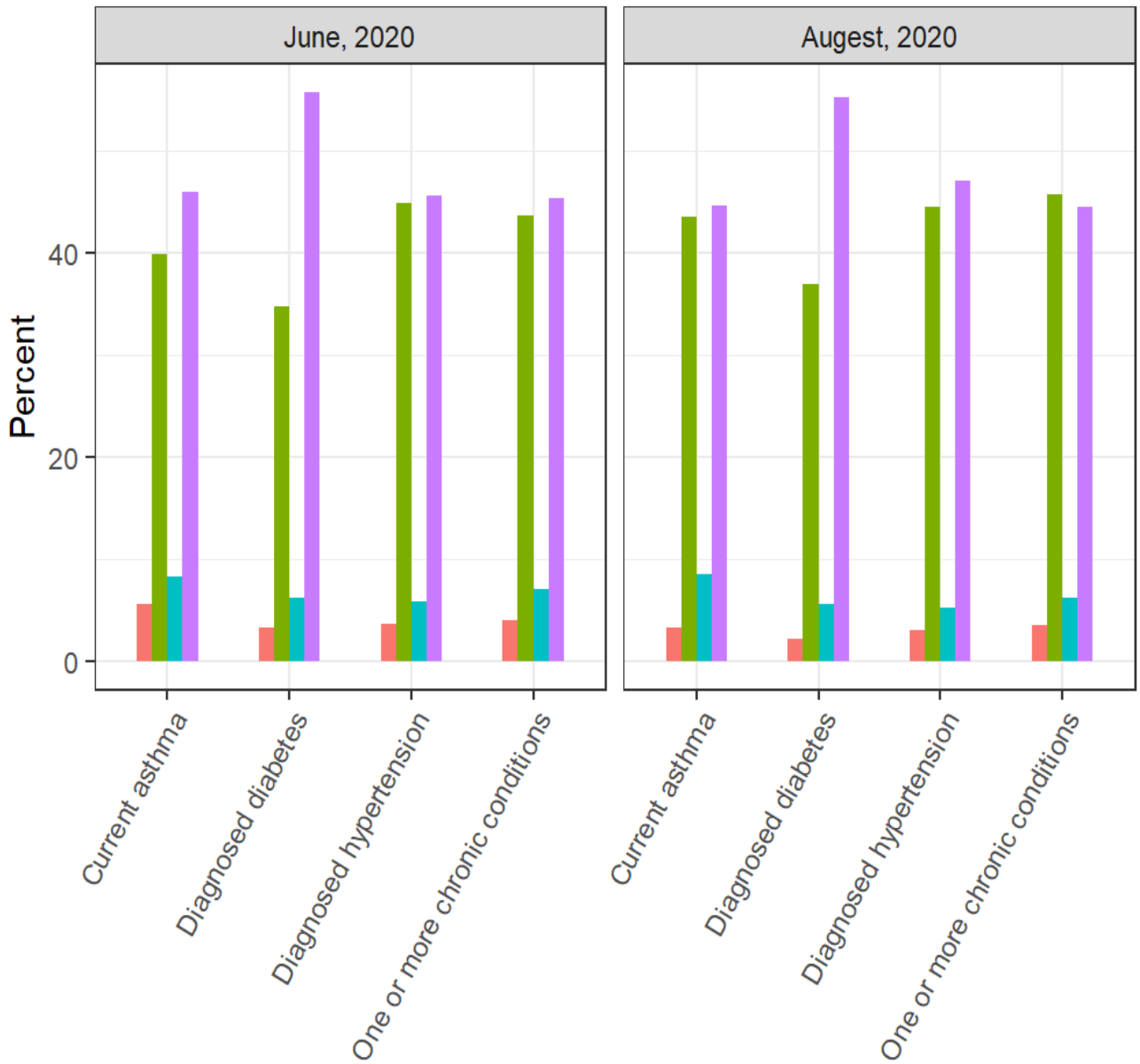

Response

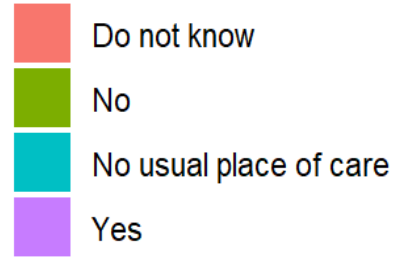

Chronic conditions 


\section{Provider Offered Telemedicine prior to Pandemic by Chronic conditions}
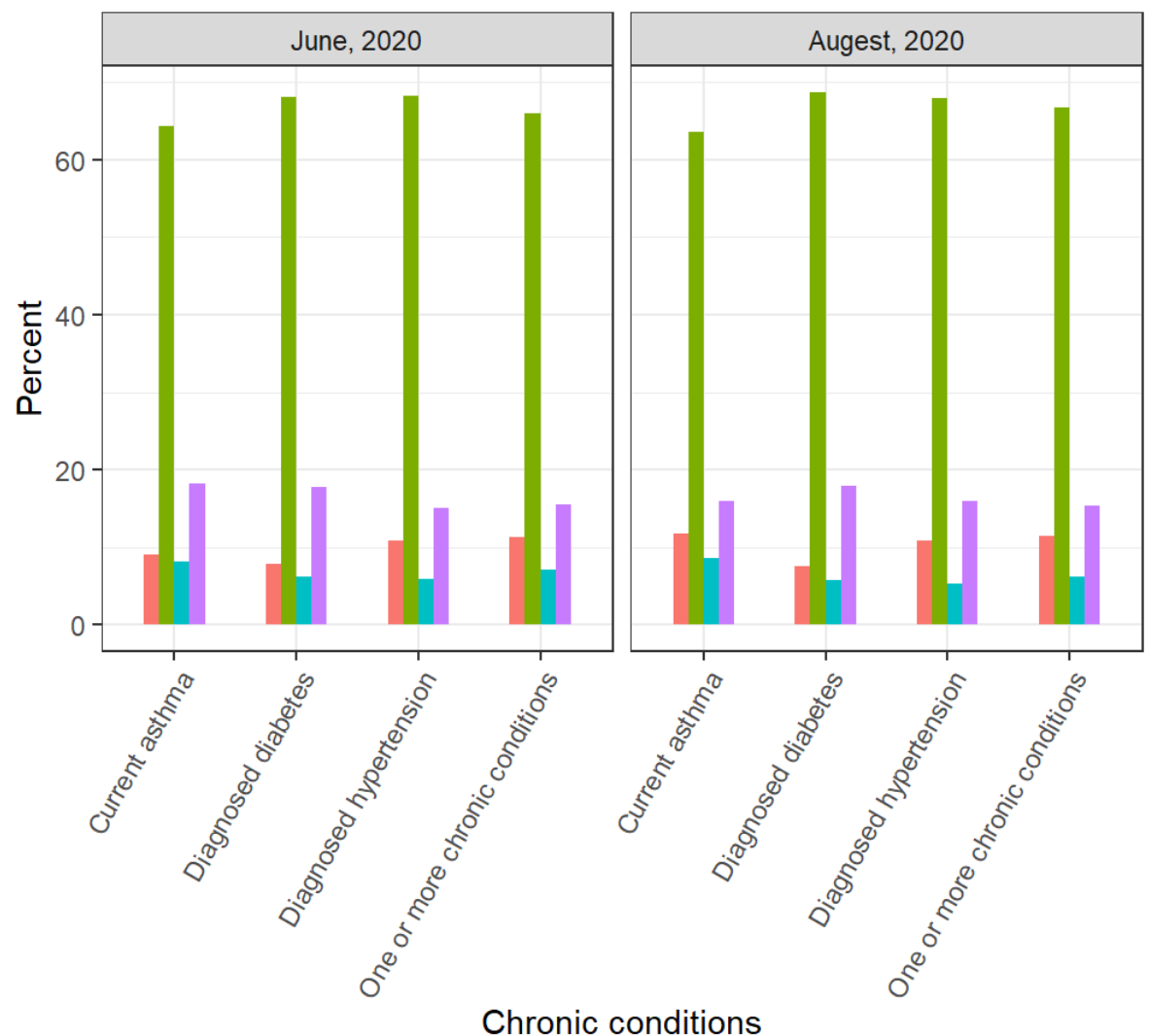

Response

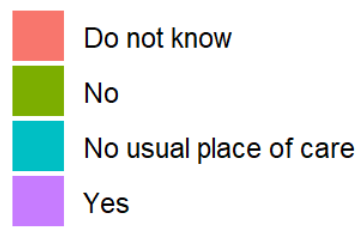

Scheduled one or more telemedicine appointments by Chronic conditions

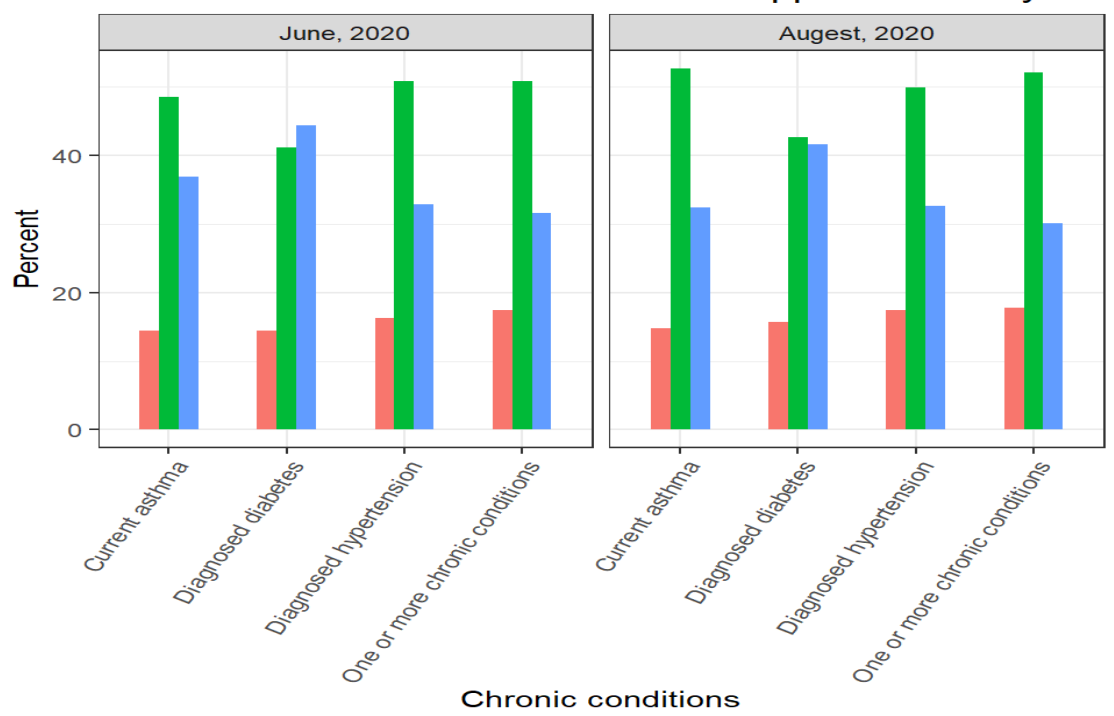

Response

No

No telemedicine available

Yes 
medRxiv preprint doi: https://doi.org/10.1101/2021.03.01.21252330; this version posted March 2, 2021. The copyright holder for this preprint (which was not certified by peer review) is the author/funder, who has granted medRxiv a license to display the preprint in perpetuity.

All rights reserved. No reuse allowed without permission.

In sum, although older people had the lowest accessibility of telemedicine before the pandemic, they have the highest access and scheduling telemedicine during the pandemic (ref). Blacks reported better access to telemedicine than other races. Males and females had the same access to telemedicine before COVID-19; however, females had higher access and scheduling after COVID-19. Before the pandemic, education was not a source of disparity to access to telemedicine, while people with higher have more access and scheduling to telemedicine than those with lower educational levels after the pandemic.

Regarding urbanization and telemedicine, it was expected to have higher access to telemedicine in the second wave, however, non-metropolitan residents reported lower access than the first wave. This study shows providers offered higher services for diabetes than other chronic. The mechanisms of this study cannot explain why patients with diabetes had more scheduling and access to telemedicine, however; it is possible that some kinds of disease are more effective to follow up by telemedicine than other chronic diseases.

\section{Discussion}

In a longitudinal survey of US residents, this study compares accessibility and scheduling telemedicine in two points of time, including before COVID-19, June 2020, and August 2020. we found a 22\% increase in offering telemedicine in six first month of the COVID-19 pandemic. $36 \%$ of the respondents reported access to telemedicine, and close to $25 \%$ of them had at least one telemedicine appointment. Access to remote healthcare services is a promising solution for providing health care during the COVID-19 pandemic for those unable to visit providers in person, which is essential for stay-at-home orders. Although the period of data collection by RAND for the second wave was short (near two months), it would be promising providers increased their remote health care services during such a critical moment like the COVID-19 pandemic. However, our finding shows almost no change in providing telemedicine between June and August. The data indicates just a $0.5 \%$ and $0.1 \%$ increase in accessing telemedicine, and scheduling in August than June, respectively. 
A primary aim of telemedicine is to reduce disparities in health care access, and the current research examines the access and scheduling of this digital tool based on demographic and socioeconomic indicators. The study by Dena (2020) examines the use of telehealth during the initial month of COVID19, which shows those aged 18-44 years are more likely to have telehealth than older age groups, and the percentage of total visits was greater among younger than older adults. However, the current study's findings indicate that the older group had a lower percentage of access before COVID-19, while they had more accessibility and scheduling telemedicine than other age groups. This result is surprising, as older age groups tend to be less engaged in digital technology, and telemedicine has not been a substantial barrier for older people anymore. Therefore, older people are more likely to adapt themselves to using remote health care services, and they have been more comfortable with technology and telehealth than in the past.

Another important finding in this study shows a reduction of disparities among Blacks and Whites by using telemedicine. Our study indicates that Blacks are more likely to use and access telemedicine during the COVID-19 pandemic than other races, which can show how telemedicine can be a vital opportunity to reduce disparities. Previous study discuss that Blacks were more likely to report they did not know how to use videoconferencing visits (10). Although the mechanism of this study cannot confirm this contradiction, this difference can be due to the type of telehealth or diseases. Future studies should concentrate on racial disparities on different types of telemedicine and diseases. In consistent with previous research, our results show that higher education and living in metropolitan areas are associated with higher using of telemedicine during COVID-19. Disparities in using telehealth are crucial to distinguish because telemedicine advocates frequently support telehealth's ability to enhance access and decrease disparities in health services utilization. However, telehealth can be a source of disparities when people who would most benefit from it are the least likely to access and use it. 
medRxiv preprint doi: https://doi.org/10.1101/2021.03.01.21252330; this version posted March 2, 2021. The copyright holder for this preprint (which was not certified by peer review) is the author/funder, who has granted medRxiv a license to display the preprint in perpetuity.

All rights reserved. No reuse allowed without permission.

Despite evidence of higher access during the COVID-19 pandemic, telemedicine has yet remained at the periphery of the US healthcare system. Although the study compares different types of chronic diseases, and people who had diabetes were more likely to schedule or access telemedicine, the data was limited to chronic diseases. More information in other health sectors can be helpful to have more accurate pictures regarding telemedicine in the US. The second wave was asked in August, which was one of the first months of the COVID-19 onset. A longer duration of information also provides more accurate results. Lastly, we could not have interactions between socioeconomic and demographic measures to examine how racial disparities would differ in educational levels, sex, and age groups.

\section{Conclusion}

Since the beginning of the COVID-19 pandemic health care system has changed its way of delivering care by providing telemedicine. This study examined factors associated with telemedicine access based on sociodemographic factors and the type of chronic disease associated with patients before and after the COVID-19 pandemic. Although telemedicine access has increased, there was no change in scheduling and access to telemedicine between June and August. Blacks and older ages had the highest access than other groups, while people with lower education or non-metropolitan areas had low access. Further research is necessary to examine how healthcare must address telemedicine's socioeconomic heterogeneity by avoiding further disparities.

\section{Code Availability}

The code to perform all analyses described in Methods and Usage Notes sections was written in R-3.6.2 and is publicly available at https://www.cdc.gov/rdc/b1datatype/rdcrands.htm

\section{Author Approval}

All authors have seen and approved the manuscript.

\section{Declaration of Conflicting Interests}

The authors declare that there is no conflict of interest. 


\section{Funding/Financial Support}

None Reported

\section{Author Contributions}

Ali Roghani designed the study and implemented methods and analyses. Samin Panahi contributed to evaluate and develop the methods, and structure. All authors were involved in developing the ideas and drafting the paper.

\section{References}

1. WHO. 2020. Q\&A on coronaviruses (COVID-19). Available from: https://www.who.int/news-room/qa-detail/q-a-coronaviruses.

2. Wadhera, R. K., Wadhera, P., Gaba, P., Figueroa, J. F., Joynt Maddox, K. E., Yeh, R. W., \& Shen, C. (2020). Variation in COVID-19 Hospitalizations and Deaths Across New York City Boroughs. JAMA, 323(21), 2192-2195. https://doi.org/10.1001/jama.2020.7197

3.Telehealth for global emergencies: Implications for coronavirus disease 2019 (COVID-19). (2020) Smith AC, Thomas E, Snoswell CL, Haydon H, Mehrotra A, Clemensen J, Caffery LJ J Telemed Telecare.; 26(5):309-313.

4. Bashshur, R., Doarn, C. R., Frenk, J. M., Kvedar, J. C., \& Woolliscroft, J. O. (2020). Telemedicine and the COVID-19 Pandemic, Lessons for the Future. Telemedicine and e-Health, 571-573. https://doi.org/10.1089/tmj.2020.29040.rb

5. Organization WHO. Telemedicine: opportunities and developments in member states. Report on the second global survey on eHealth: world health Organization; 2010

6. Monaghesh, E., Hajizadeh, A. The role of telehealth during COVID-19 outbreak: a systematic review based on current evidence. BMC Public Health 20, 1193 (2020). https://doi.org/10.1186/s12889-020$\underline{09301-4}$ 
medRxiv preprint doi: https://doi.org/10.1101/2021.03.01.21252330; this version posted March 2, 2021. The copyright holder for this preprint (which was not certified by peer review) is the author/funder, who has granted medRxiv a license to display the preprint in perpetuity. All rights reserved. No reuse allowed without permission.

7. Ellerie Weber, Sarah J Miller, Varuna Astha, Teresa Janevic, Emma Benn, Characteristics of telehealth users in NYC for COVID-related care during the coronavirus pandemic, Journal of the American Medical Informatics Association, Volume 27, Issue 12, December 2020, Pages 1949-1954,

8.Fordham, M., Lovekamp, W., Thomas, D., \& Phillips, B. (2013). Understanding social vulnerability. In D. Thomas, B. Phillips, W. Lovekamp, \& A. Fothergill (Eds.), Social vulnerability to disasters (2nd ed., pp. 1-32). Taylor \& Francis.

9. Kim, S. J., \& Bostwick, W. (2020). Social Vulnerability and Racial Inequality in COVID-19 Deaths in Chicago. Health Education \& Behavior, 47(4), 509-513. https://doi.org/10.1177/109019812092967

10.Fischer, S. H., Ray, K. N., Mehrotra, A., Bloom, E. L., \& Uscher-Pines, L. (2020). Prevalence and characteristics of Telehealth utilization in the United States. JAMA network open, 3(10), e2022302e2022302.

11. Chen, J., Amaize, A., \& Barath, D. (2020). Evaluating Telehealth Adoption and Related Barriers Among Hospitals Located in Rural and Urban Areas. The Journal of Rural Health.

12. Jaffe, D. H., Lee, L., Huynh, S., \& Haskell, T. P. (2020). Health Inequalities in the Use of Telehealth in the United States in the Lens of COVID-19. Population health management, 23(5), 368-377. https://doi.org/10.1089/pop.2020.0186 
medRxiv preprint doi: https://doi.org/10.1101/2021.03.01.21252330; this version posted March 2, 2021. The copyright holder for this preprint (which was not certified by peer review) is the author/funder, who has granted medRxiv a license to display the preprint in perpetuity.

All rights reserved. No reuse allowed without permission. 